This document is the accepted manuscript version of a published work that appeared in final form in the British Journal of Midwifery, copyright (c) MA Healthcare, after peer review and technical editing by the publisher. To access the final edited and published work see http://www.magonlinelibrary.com/doi/10.12968/bjom.2015.23.4.282

\title{
What are OERs and MOOCs and what have they got to do with Prep?
}

\begin{abstract}
As technology advances and becomes more accessible, it offers midwives a greater variety of ways to meet Prep (Continuing Professional Development) Standards (NMC, 2011) and, at the end, of 2015 its successor Revalidation. The concepts of online learning and open educational resources (OERs) have developed rapidly in the last two decades due to advances in, and the massification of, information technology. The term "Massive Open Online Courses" was devised by Dave Cormier in 2008 in response to the development of free, open, online courses which allow for an unlimited number of participants (Cormier, 2010). As OERs and MOOCs are free and easily accessible, could they be useful resources for midwives to access to meet CPD requirements? This article will explain what they are; suggest how they might be useful and recommend some resources for you to consider.
\end{abstract}

\section{Keywords}

Massive Open Online Courses; MOOCs; Online Learning; Open Educational Resources; OERs; Continuing Professional Development; Revalidation.

\section{Background}

As autonomous, accountable practitioners, midwives are required to continually update their clinical knowledge and skills in order to provide high quality, safe and effective care (Nursing and Midwifery Council (NMC), 2012; NMC, 2015; Jokhi, 2014). Post-registration education and practice (Prep) is a set of NMC standards and guidance designed to support midwives in providing this level of care. Midwives renew their registration every three years by signing a Notification of Practice (NoP) and submitting an annual Intention to Practise (ItP) form to their named Supervisor of Midwives. Prep standards have two distinct requirements: midwives must provide evidence of a minimum of 450 hours of practice plus the equivalent of 35 hours of continuing professional development (CPD) or learning activity in the previous three years in order to maintain their professional registration (NMC, 2011). The NMC ensures midwives are 
complying with the standards by the NoP and may ask midwives to provide written evidence of their learning activity by means of audit. Under the current guidance, whilst the learning activity must be relevant to practice, there is no such thing as approved Prep (CPD) learning activities (NMC, 2011), it is down to the individual to choose an activity they feel is relevant to practice and provide written evidence of its positive influence on their practice.

\section{Revalidation: all change?}

Revalidation is being introduced at the end of 2015 and aims to increase public confidence in nursing and midwifery by promoting a culture of professionalism and accountability. The NMC is currently consulting on revising CPD requirements, including exploring whether to be more prescriptive in identifying suitable CPD activities. The main changes from the current requirements are the increase of CPD hours from 35 to 40 hours (20 of which should involve interaction with others) and 5 reflective accounts based on the collection and reflection on feedback on practice from women and peers, CPD and the revised Code (NMC, 2014).

In preparation for the introduction of Revalidation, the NMC, as part of its Revalidation Evidence Report (2014), asked nurses and midwives what CPD activities they undertook and the responses included traditional activities such as workshops and conferences ( $84 \%$ of respondents); reading and reviewing relevant publications ( $81 \%$ of respondents); mandatory training (non-clinical) (65\% of respondents) and group or practice meetings (61\%). Interestingly $74 \%$ of respondents stated they used the internet as a resource. With barriers to completing CPD including difficulties with getting protected learning time from employers; cost and fitting CPD around working patterns and family life, a rethink of how to achieve CPD was required and so it was felt online learning was an acceptable, practical solution (NMC, 2014).

Internet research and online learning or 'learning facilitated and supported through the use of information and communications technology' (Carroll et al., 2009: 236) come in many forms: the Royal College of Midwives' (RCM) elearning platform 'i-learn' is a learning resource with over 50 online courses, free to RCM members; however if you are looking for totally cost-free online learning then OERs or MOOCs may be worth considering. So what are they?

\section{What is an OER?}

Open educational resources (OER) are learning and teaching materials, freely available online for anyone to use; examples of which are full courses, modules and lectures (JISC, 2015). They are shared via websites of education providers and through public services such as JORUM and Slideshare.

OERs: How can they support CPD? Some examples 


\begin{tabular}{|c|c|c|}
\hline JORUM & $\begin{array}{l}\text { Diabetes in Pregnancy } \\
\text { Timeline }\end{array}$ & $\begin{array}{l}\text { This interactive tool shows the care plan for a } \\
\text { diabetic woman throughout pregnancy and } \\
\text { childbirth. It is aimed at student midwives as it } \\
\text { is intended to give a basic overview of the care } \\
\text { provided and includes links to other useful } \\
\text { resources. The timeline might also be useful for } \\
\text { practising midwives as a refresher. }\end{array}$ \\
\hline JORUM & The Biology of Pain & $\begin{array}{l}\text { A visual representation of the anatomy and } \\
\text { physiology of pain which includes editable links } \\
\text { to online resources. }\end{array}$ \\
\hline JORUM & Reflection in Learning & $\begin{array}{l}\text { Two videos introducing the role of reflection in } \\
\text { learning and reflection in problem solving. }\end{array}$ \\
\hline Slideshare & Search 'midwifery' & 3,347 resources available \\
\hline Slideshare & Search 'maternity care' & 31,636 resources available \\
\hline Slideshare & $\begin{array}{l}\text { Search 'Nursing and } \\
\text { Midwifery Council' }\end{array}$ & 9,539 resources available \\
\hline
\end{tabular}

\section{What is a MOOC?}

A MOOC is a Massive Open Online Course. The aim of a MOOC is unlimited participation (anyone with an internet connection can sign up); with no prerequisites needed; have no "credit" attached to them and are usually free. The most well know providers are Coursera (2015) led by the University of Stanford; edX (2015) led by MIT and Harvard University; FutureLearn (2015) which is UK based and Udacity (2015) led by Google.

\section{MOOCs: How they developed}

The first MOOC was hosted by the University of Manitoba, Canada in 2008 entitled "Connectivism and Connective Knowledge" (Sandeen, 2013). The hosts were surprised when over 2,000 participants enrolled with little advertising. The expansion of online educational video content providers such as TED (2015) has led to the proliferation of MOOCs. By 2012 which is referred to as "the year of the MOOC" most of the main providers had been established and some MOOCs were attracting more than 100,000 participants.

MOOCs are offered via virtual learning environments and include video; peer learning/assessment; e-tivity tasks; discussion boards; wikis and journals. As time has gone on some MOOCs are offered with credit but these often involve a fee to register and to be assessed.

MOOCs: How can they support CPD? Some examples

\begin{tabular}{|c|c|l|}
\hline Host & Course Title & \multicolumn{1}{c|}{ Description } \\
\hline $\begin{array}{c}\text { Openeducation. } \\
\text { blackboard.com }\end{array}$ & $\begin{array}{c}\text { Study Skills for } \\
\text { Academic Success }\end{array}$ & $\begin{array}{l}\text { An interactive and participative course designed } \\
\text { to improve academic skills and confidence of } \\
\text { students new to, or preparing for, Higher } \\
\text { Education }\end{array}$ \\
\hline Futurelearn & Understanding & How do addictions develop? How are they best \\
\hline
\end{tabular}




\begin{tabular}{|c|c|c|}
\hline & $\begin{array}{l}\text { Drugs and } \\
\text { Addiction }\end{array}$ & treated and prevented? \\
\hline Futurelearn & $\begin{array}{l}\text { The Science of } \\
\text { Medicines }\end{array}$ & $\begin{array}{l}\text { Learn the science behind how and why } \\
\text { medicines work and what can improve patient's } \\
\text { treatment. }\end{array}$ \\
\hline Futurelearn & $\begin{array}{l}\text { Obesity: Causes } \\
\text { and Consequences }\end{array}$ & $\begin{array}{l}\text { Obesity is a global epidemic. As the world gets } \\
\text { fatter, explore its impact on our health and } \\
\text { lives. }\end{array}$ \\
\hline Futurelearn & $\begin{array}{l}\text { Introduction to } \\
\text { Cyber Security }\end{array}$ & $\begin{array}{l}\text { Gain essential cyber security knowledge and } \\
\text { skills, to help protect your digital life. }\end{array}$ \\
\hline
\end{tabular}

\section{Application to practice}

The aim of this article was to introduce you to alternative ways of achieving Prep Standards (NMC, 2011) using free online resources. OERs and MOOCs have potential as suitable learning activities to underpin evidence-based practice under the current Prep Standards.

Revalidation will be introducing changes to Prep including the potential for more prescriptive Prep activities and the requirement for 5 reflective accounts during the preceding 3 years. The Centre for Achievement and Performance (CfAP) at the University of Northampton has developed a MOOC entitled "Study Skills for Academic Success". Whilst this was initially targeted at healthcare students new to, or preparing for, Higher Education, it could also be a useful resource for qualified midwives to access to develop their confidence in their writing skills in preparation for Revalidation (available on the Open Education platform powered by Blackboard:

https://www.coursesites.com/webapps/Bb-sites-course-creation-

BBLEARN/courseHomepage.htmlx?course_id=_326463_1.)

Participants in the NMC Consultation (2014) wanted clear guidance on the expectations and requirements for the 5 reflective accounts, including format, comprehensiveness and academic level. It was also requested that it be easy to complete; have headings to help with structuring; not require academic referencing and include suggestions for appropriate topics.

In 2001, Rolfe, Freshwater and Jasper published "Critical Reflection for Nursing and the Helping Professions: A User's Guide". Since its publication, this model of reflection, often known colloquially as, "What? So What? Now What?" has been used successfully by healthcare professionals, including midwives to reflect on practice. The statement "What? So What? Now What?" simplifies the concept of reflection; however within each of the three trigger questions, are deeper, more searching questions, which are outlined in the table below:

Summary of Rolfe, Freshwater and Jasper's Model of Reflection (2001)

What? ...was I trying to achieve? ..was the response of others? 


\begin{tabular}{|l|l|}
\hline & $\begin{array}{l}\text {...was my role in the situation? } \\
\text {...were the consequences of my actions? } \\
\text {...was good (or bad) about the experience? }\end{array}$ \\
\hline So what? & $\begin{array}{l}\text {...does this tell me about...? } \\
\text {...was I thinking at the time? } \\
\text {...are the other issues in this situation? } \\
\text {...is my new understand of the experience? }\end{array}$ \\
\hline Now what? & $\begin{array}{l}\text {...do I need to do to make things better? } \\
\text {...are there any other issues to deal with? } \\
\text {...are the consequences of these actions? }\end{array}$ \\
\hline
\end{tabular}

\section{So what?}

Midwives need to be creative to successfully juggle the demands of clinical practice, regulation and their private lives. Online learning offers great flexibility to meet such demands so why not sign up to the MOOC to refresh your writing skills and try out Rolfe et al's user-friendly reflective model - in the words of a famous supermarket 'Every little helps!'

By

Alison Power

Senior Lecturer (Midwifery), The University of Northampton

and

Kathryn Coulson

Head of Centre for Achievement and Performance, The University of Northampton 


\section{Reference List}

Centre for Achievement and Performance (2015) Academic Support. University of Northampton. [Online]. Available from:

https://nile.northampton.ac.uk/webapps/portal/execute/tabs/tabAction?tabId= $\underline{7271} 1$ \&tab tab group id $=2531$ [Accessed: 26 ${ }^{\text {th }}$ February 2015].

Cormer, D. (2010) What is a MOOC? YouTube. [Online]. Available from: https://www.youtube.com/watch?v=eW3gMGqcZQc [Accessed: $26^{\text {th }}$ February 2015].

Coursera (2015) Take the World's Best Courses. [Online] For Free. Coursera. [Online]. Available from: https://www.coursera.org/ [Accessed: $26^{\text {th }}$ February 2015].

edX (2015) Take Great Online Courses from the World's Best Universities. edX. [Online]. Available from: https://www.edx.org/ [Accessed: 26 th February 2015].

FutureLearn (2015) Upcoming Courses. FutureLearn. [Online]. Available from: https://www.futurelearn.com/courses/upcoming [Accessed: $26^{\text {th }}$ February 2015].

Gibbs, G. (2001) Learning by Doing. Geography Discipline Network. [Online]. Available from: http://www2.glos.ac.uk/gdn/gibbs/index.htm [Accessed: $4^{\text {th }}$ March 2015].

Johns, C. (2000) Becoming a Reflective Practitioner. Oxford: Blackwell Science.

Nursing and Midwifery Council (NMC) (2015) Revalidation. NMC [Online]. Available from: http://www.nmc-uk.org/Nurses-and-midwives/Revalidation/. [Accessed: $27^{\text {th }}$ February 2015]

Nursing and Midwifery Council (NMC) (2014) Revalidation evidence report. NMC [Online]. Available from: http://www.nmc-

uk.org/Documents/Consultations/2014/Revalidation-evidence-report.pdf.

[Accessed: $5^{\text {th }}$ March 2015]

Nursing and Midwifery Council (NMC) (2011) The Prep Handbook. NMC [Online]. Available from: http://www.nmc-uk.org/Documents/Standards/NMC Prephandbook 2011.pdf. [Accessed: 27 $7^{\text {th }}$ February 2015]

Rolfe, G., Freshwater, D., and Jasper, M. (2001) Critical Reflection in Nursing and the Helping Professions: A User's Guide. Basingstoke: Palgrave Macmillian.

Sandeen, C. (2013) Integrating MOOCs into Traditional Higher Education: The Emerging "MOOC 3.0" Era. Change: The Magazine of Higher Learning. 45 (6), p34-39.

TED (2015) TED: Ideas Worth Spreading. TED. [Online]. Available from: http://www.ted.com/ [Accessed: 26 ${ }^{\text {th }}$ February 2015]. 
Udacity (2015) Project-based Online Courses and Curriculums to Master Skills That Count. Udacity. [Online]. Available from: https://www.udacity.com/ [Accessed: 26 ${ }^{\text {th }}$ February 2015]. 
